\title{
Accounting System and Financial Performance Measurements ${ }^{\#}$
}

\author{
Zbyněk HALÍR $\check{R}^{*}$
}

\section{Introduction}

Recently significant changes have taken place in society and business environment, in the pressure on business subjects and in the requirements of owners, managers, banks and other stakeholders for ensuring adequate information. These changes are reflected (among other things) also by need to consider practical ways of use traditional tools and methods of performance management. Undoubtedly management accounting which is often referred to as the backbone of information management ranks among these tools.

Ensuring a satisfactory performance level is one of the fundamental prerequisites for the successful development of each company. Securing abundance of high quality information, which reflect the level of business performance and help all involved bodies to understand in what direction and why the performance is developed, as well as the possibility of controlling the way they should develop, requires the existence of quality and complex information system and management control system. Under the terms of such a corporate information system, particularly in matters relating to financial performance, an accounting subsystem plays an important role. Accounting is always associated with decision-making tasks of various subjects and therefore it should enable them to take the right decisions related to the company.

\footnotetext{
\# The article is processed as an output of a research project The Role of Accounting Information in Financial Performance Measurements registered by the Internal Grant Agency (University of Economics, Prague) under the registration number F1/21/2010 and research plan Development of Accounting and Financial Theory and its Application in Practice from Interdisciplinary Point of View under the registration number MSM 6138439903.

Ing. Zbyněk Halîr - Ph.D. student; Management Accounting Department, Faculty of Finance and Accounting, University of Economics, Prague, W. Churchill Sq. 4, 13067 Prague, Czech Republic; <zbynek.halir@vse.cz>.
} 
This paper is a follow-up to an earlier one, which was processed within the project supported by the Internal Grant Agency of UEP "The Role of Accounting Information in Financial Performance Measurements". The core of an earlier output was measuring and assessing financial performance by external users of financial information (Halír, 2010). This paper focuses on performance management from managers' viewpoints, thus enriches the previous output with a new perspective on the issue of performance measurement. The paper simultaneously tries to compare both approaches, if it is desirable.

On the other hand, it should be noted that although the financial performance seems to be a key factor in the management control, it is still only a partial aspect that affects more complex performance at a broader level of understanding. The relationship between generally conceived performance and financial performance of the company (primarily from manager's point of view) will be an issue of further research and conclusions will be published in subsequent papers.

The paper discusses the role of management accounting in performance management. It seeks to clarify the relationship between management accounting system and performance management system. Both of them can be understood as subsets of management control system in general, but they perform different roles within it. Then the paper deals with a dual concept of measuring and managing financial performance. It emphasizes different information needs of different groups of users with key regard to managers (internal users of management accounting information).

In this regard, the paper (and the related research) focuses mainly on the following objectives:

- to analyze the role of management accounting in performance management system and to assess its importance, but also highlight areas where management accounting suffers from its limitations,

- to assess to what extent the information needs of managers are compatible with the information needs of external users, and consequently to consider whether it is better to design two separate information systems for external and internal users or prefer the pursuit of their unification. 


\section{Performance as a Quantity}

\section{Performance of an Enterprise and its Management}

Business performance can be generally defined as the characteristic, which assesses whether the business process helps to achieve business goals within a defined time period. If so, this characteristic should also measure the extent it occurs and assess what factors contribute to it. According to Wagner (2005) the above definition implies the following context: The objectives of an enterprise are resultant of objectives of all subjects that enter into a relationship with the company. The assessment always depends on the questions for whom and for what purpose is the performance assessed (assessment of performance is a purpose-oriented evaluation).

This observation is very closely tied to a dual conception of the financial and management accounting. This issue will be discussed in chapter "Dual Concept of Financial and Management Accounting".

Other sources characterize performance measurement in the same way - for example as "the process of assessing the proficiency with which a reporting entity succeeds, by the economic acquisition of resources and their efficient and effective deployment, in achieving its objectives" (See CIMA, 1982).

Determination of targets and objectives of different involved subjects is crucial for the interpretation and conception of performance. The traditional determination of the objectives of an enterprise was historically oriented primarily to maximizing value for business owners. This concept is based on shareholders theory. The performance achieved is then understood primarily as increasing the value of capital invested by the owner of the company. This kind of performance can be suitably described by the financial measures, which results in understanding the performance only as its financial (value) component. Whether financial measures can reflect generally conceived business performance or not will be examined in the chapter "The Relationship between Financial Performance Measurement and Management Accounting".

In the course of time stakeholders theory has more and more forcefully come in useful. This theory is based on the assumption that the aim of the company is not only to meet the expectations of its owners, but 
also expectations of other interested bodies in its vicinity (Stakeholders). For many of these interested subjects many aspects are more important than the company's financial results. Performance is then to be understood in a broader context. In such a situation it is not possible to simplify the performance by reducing to its financial (value) component. This extensively perceived performance can no longer be assessed solely through financial (value) indicators and measures that are not able to evaluate non-financial ${ }^{1}$ aspects of business.

While managing performance the managers strive to influence the economic subjects' development by a rational way - so that they would be able to fulfill the aims they have been founded for (see Král, 2007). High-quality and sophisticated performance measurement system is one of the fundamental prerequisites for the successful business process management. The status of performance measurement system within the enterprise information system will be further discussed in the chapter "The Relationship between Financial Performance Measurement and Management Accounting".

\section{Financial Performance of an Enterprise}

In the previous chapter a view on the entrepreneurial process which assesses the level of achieved performance in a comprehensive way was described. Only a comprehensive and complex performance reflects how the firm leads in a competitive environment and what its future growth prospect is like. Financial performance, which is based on traditional accounting measures, is hierarchically subordinated item of a complex evaluation of company's performance. It is "only" a subset of such holistically understood performance.

The reason for this subordination is obvious: financial performance of the company, of course, needs to be assessed using financial criteria. Over time - and especially in recent years - the future potential of performance has been increasingly emphasized. The main importance of information on company's performance is not in the retrospective assessment of the economic events, but in providing a basis for deciding on options of future development. The main task of measuring performance is according to Wagner (2005) - to help to find answers to questions how

Examples of non-financial aspects can be "quantities" such as customer satisfaction and loyalty, the level of corporate culture, ability of the company to innovate, etc. 
Halír, Z.: Accounting System and Financial Performance Measurements.

our present and future decisions and actions contribute to the future benefit.

If we emphasize the strategic potential of performance of continuously ongoing business process a number of effects prove in a way that financial measures are not able to capture, or they prove even in opposite way than how these effects are reflected in the accounting. Accounting is tactically and operationally oriented tool and therefore sometimes fails to reflect and satisfy the requirements for information support of strategic management. The financial performance measures and benchmarks are in accordance with the usual traditional business objective, which is raising the value for the owner of the company, however it may give misleading information about the broadly perceived performance that reflect the extent to which the firm has complied with the objectives of all stakeholders.

Many analytical performance measures are based on the above mentioned criticism. They are based on the idea that the performance of the company can be better described by a wide range of indicators that are directly tied to the level of future economic benefit, rather than by the general estimate of future benefit, that is expressed by one comprehensive (synthetic) measure. Systems of analytical performance measures 2 are definitely much more suitable tools for the assessment and management of comprehensively understood and strategically oriented performance. That is, especially, for the following reasons:

2 Perhaps the best known and the most sophisticated system of analytical performance measures is the concept of Balanced Scorecard (BSC), which integrates criteria and tools that were previously used mostly in isolation. It identifies relationships between four major prospects and links them with business vision and business strategy. A major contribution of this approach is a new understanding of the financial perspective. It is the attempt to create a more comprehensive measurement system of company's performance. Traditional measures considered the level of financial indicators as a determining factor in business performance. Thanks to the BSC concept much greater attention to the scales and measures, which are an important indicator of business performance in strategic time horizon, began to be given. The level of care for employees began to be taken into consideration as well as the way the company appears to its customers; it is also possible to express how important are the innovative activities, etc. Only as the impact of reaching the desired level of socalled value drivers, the objectives in terms of financial performance measures (socalled value results) can be met. 
- system contains natural criteria and measures, which have essential significance for assessing the financial performance in the long (strategic) run;

- wide range of indicators allows their decomposition into subindicators, which are better understood by responsibility centres, which stand at a lower hierarchical level of organizational structure; it has a positive effect on their motivation, working moral and mutual communication and integration;

- every company can create a system of measures and benchmarks, which will support its strategy and ensure its linkage with top objectives of the company;

- for all the above-mentioned reasons a comprehensive system of indicators is more effective management tool.

All of us assess some kind of performance in everyday life. Whatever activity people are engaged in, they always consider what has to be sacrificed on one hand and what does the activity bring them on the other hand. By mutual comparison of sacrifices and benefits the individual comes to the conclusion on what level of performance he or she has acted.

Such a general view can also be applied to business activity. The essence of business process is always the transformation of inputs to outputs. Inputs that were incurred in business process correspond to sacrifices that were mentioned above and outputs, which are gained thanks to the business process, then correspond to benefits that were mentioned above.

If all the inputs and outputs are measured using financial (value) quantities, we assess the financial performance of the company. In order to reach the desired level of financial performance, it is necessary that the value of total output exceeds the value of total input. The main motive of business is a general appreciation of inputs by gaining a higher output value.

Financial performance of a company can be generally defined as the characteristic, which assesses whether the business process helps to achieve financial (value) objectives that have been set. If so, this characteristic should also measure the extent it occurs and what factors contribute to it. 
Fig. 1: Transformation Process

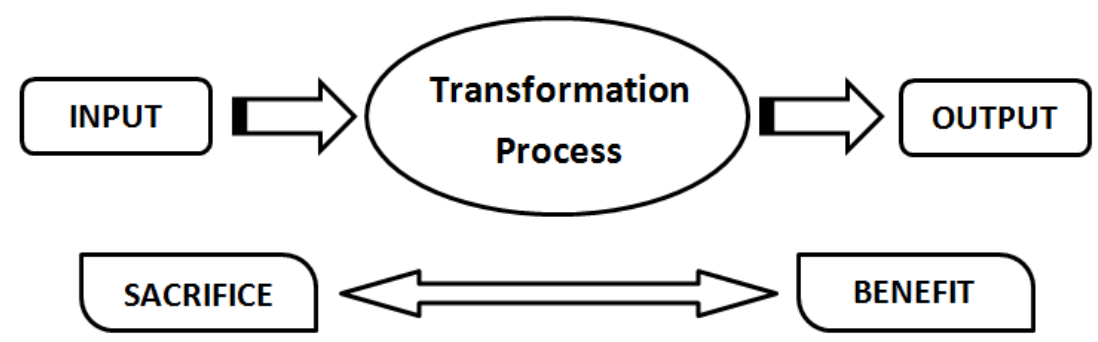

Source: Inspired by Fibírová - Šoljaková - Wagner (2005).

From the relationship between costs incurred and economic benefits gained some important criteria for the rational development of the business process can be derived. The most important of these are measurements of economy, efficiency and effectiveness. Economy is rationality in the use of economic resources. The aim is to achieve desired outcomes at minimum cost. The effectiveness balances incurred costs against achieved economic benefits. This disparity is usually quantified by profit. Finally, efficiency is the ratio of effectiveness (i.e. profit) related to the total of economic resources employed.

\section{Content and Scope of Management Accounting}

It is necessary to define some additional concepts before examining the relationship between performance measurement system and management accounting system. The performance and its conception were discussed in the previous chapter. Now it is necessary at least briefly define the content and conception of management accounting. These issues will be furthermore elaborated in subsequent chapters of this paper. Meeting the objectives of this paper requires not only assessing the role of management accounting in business performance measurement, but also assessment of the role of accounting in general in this process.

Management accounting is a very important tool for measuring and subsequently managing the financial performance of an entity.

Methods and tools of management accounting in various companies largely differ. It results in the lack of a coherent approach to management accounting. Almost all professional texts, which are focused on accounting theory, are aimed primarily on financial accounting. Publications aimed 
at the management accounting are then engaged in particular applications of management accounting tools in than conceptual issues of accounting theory.

Despite the absence of a comprehensive approach we can find a number of content definitions of management accounting. For example the definition of the Chartered Institute of Management Accountants (CIMA) of the United States of America can be mentioned: "Management accounting is the application of the principles of accounting and financial management to create, protect, preserve and increase value to the stakeholders of profit and not-for-profit enterprises, both public and private. Management accounting is an integral part of management, requiring the identification, generation, presentation, interpretation and use of information relevant to:

- formulating business strategy;

- planning and controlling activities;

- decision-making;

- efficient resource usage;

- performance improvement and value enhancement;

- safeguarding tangible and intangible assets;

- corporate governance and internal control" (see CIMA, 1982).

During recent years management accounting has undergone continuous development. ${ }^{3}$ One of its key features is the fact that it has been increasingly extending beyond the principles of double-entry accounting. That is because of the requirements for timeliness and originality of various reports and other information. Other methodological elements are often applied in a modified form. Management accounting is thus understood as a system of value (financial) information aimed at purposeful selection of both accounting information and information from other subsystems of the information system of an enterprise as well as from the surrounding environment. The motivation of carrying out such special-purpose selections of information is to provide as wide range of information for decision making as possible.

The result of the need to ensure information support for emerging methods and tools for measuring performance management accounting covers information that is beyond accounting method. When management

\footnotetext{
3 Developmental tendencies are discussed below in more detail.
} 
Halír, Z.: Accounting System and Financial Performance Measurements.

accounting seeks to integrate such information into its field, it goes beyond traditionally-based accounting system. This aspect we will be discussed in the chapters "Dual Concept of Financial and Management Accounting" and "Trends in the Conception of Performance and Development of Management Accounting".

\section{Dual Concept of Financial and Management Accounting}

The company must be seen as component of a complex network of relationships. Each entity that is part of this network, aims primarily to meet its own goals and achieve its own economic benefit. However, it is also important to highlight that the issue of meeting different objectives naturally brings the need to make different decisions and consequently the need for differentiation of source information. The one and only economic reality must be examined from many different perspectives. Narrow specialization and disciplinary perspective, which enabled a rich analysis of the economic situation from a specific point of view seems to be insufficient. The present development requires an interdisciplinary perspective; the reality needs to be explored inclusive all the linkages and causalities.

Performance evaluation is also dependent on questions for whom and for what purpose the performance is assessed. From the managers' perspective performance is generally regarded a very broad-based characteristics, which assesses the extent the subject fulfils its objectives. On the contrary, external users' perspective on the financial performance is limited by the financial accounting regulation or by the legislation in many countries (including the Czech Republic).

\section{Performance Measurement and its User Differentiation}

The very first question that should always be related to performance measurement is: "For whom do we actually measure the performance?" In general, it is possible to answer: "For anyone who has something to do with the company and therefore needs to be informed about its performance". On the other hand, not all stakeholders perceive and understand the performance in the same way. This is because each of them uses the information obtained by other means. 
It is purposeful to divide all the involved subjects into two groups according to whether they have the opportunity to directly influence the activities, whose performance is under consideration, or haven't. External users have many reasons to be interested in business performance. Wagner summarizes the most important of reasons as follows (for more details see Wagner, 2009, pp. 55 - 56):

- they need to reach a decision about their relationship to the organization;

- they need to enforce their rights to the organization;

- they need to influence the direction of development of the organization;

- they need to regulate performance and behavior of agents;

- they need to compare the performance of the organization to other subject's performance.

Internal users also have many reasons to be interested in the company's performance. The essence of all these reasons is conception of performance measurement, which is understood by the internal users not only as a desire to obtain "mere" information about the performance, but especially as high-quality information support for management control. In order to have good business prospects for survival in the long run, it is necessary to look far enough into the future when managing and influencing business activities to achieve a satisfactory level of performance. Factors that determine the long-term growth potential (employee skills, customer satisfaction and loyalty, corporate databases, etc.) are either very difficult measurable or not measurable at all in the accounting system. The only financial measures have already ceased to reflect the evolution of this dimension of performance and should be enriched with non-financial, especially strategically oriented criteria. On the other hand, financial measures have a kind of sovereign status. Fulfillment of the objectives of the company and all stakeholders is eventually just the proper way to achieve good financial results (financial performance) in the strategic time horizon.

In the context of the above-mentioned differentiation of decisionmaking tasks of individual subjects that are interested in the business, it is necessary to adequately distinguish the data within the accounting system. The natural result of these claims is the separation of accounting designed for external users (i.e. interest groups outside the enterprise) from 
Halír, Z.: Accounting System and Financial Performance Measurements.

accounting designed for internal use (accounting as an information support of management control).

The natural emergence of two separate accounting systems may not and even should not in my opinion - necessarily imply two different approaches to the conception of performance measurement. The different needs of different users require a different structure and sometimes even different content of output information or statements about the performance achieved, but they not require different conception of performance itself. The information technology has developed and expanded in such way that they offer almost limitless possibilities of supporting managerial decision making and management control as well as possibilities of ensuring the information needs of all other stakeholders.

If the external and internal users require different information it is not necessary - what is more, it is not even correct during the boom of database tools and technologies - to archive this information in two different data stores in a different structure for each of them. The correct way is archiving of data in one central data store, in which each piece of information has a number of different attributes that reflect different views of different groups of users. Differentiated demands for performance information is then simply a matter of filtering data in the required database dimension and required structure. It is not a matter of the need to obtain different underlying data.

This consideration can be further generalized. This integration goes far beyond areas of financial and management accounting and associates data of many professional disciplines such as marketing, management, logistics or others, including information from the external environment of the company. Only such a complex integration of information allow comprehensive assessment of business performance, regardless of whether the entity's performance is assessed by subjects standing inside or outside the company.

\section{The Impact of Dual Conception on Performance Measurement}

All the above manifestations of duality in the concept of financial and management accounting are also reflected in the performance measurement, of course. 
From the mutual status of the owner and the management of a company four basic functions of performance measurement can be derived. Performance measurement can be understood as:

- information support of management control; ${ }^{4}$

- information support of owners' decision-making tasks; ${ }^{5}$

- information support of decision-making tasks of other interest groups (stakeholders); ${ }^{6}$

- information support for the assessment of managerial performance. $^{7}$

The first mentioned function relates to the comprehensive (managerial viewed) performance with all its specifics. Management accounting system with its tools and outcomes is the data source for assessing the performance of this type. The remaining three functions bind to the financial performance, which assessment is based primarily on data provided by the financial accounting system. This way the performance is understood by external subjects standing outside the company.

4 The information on the financial performance helps managers to verify, if the required level of performance corresponds to the expected. Then, managers should identify and analyze any deviation and identify the causes of their origin. Significant deviation is desirable to examine in more detail. It is suitable to examine the factors that contribute to its formation and trace its implications for the business process. Quality analysis helps to assess the prospects of future performance and to correct identified negative deviations.

5 Information on the financial performance of the enterprise should help the company 's owners to answer the question: "What development can be expected in future periods?". The owner must be able to use this information to make an informed decision about their future relationship with the company. We can therefore say that the owner is interested mainly in the performance of the business process as a whole.

6 As in the case of the first mentioned function in this case it is the performance of the business process itself. The other interest groups are interested in future business prospects and they need to decide on its future relationship with the company.

7 Thanks to information on the performance of the company its owner is able to determine whether managers are acting as expected. Following these findings the owner makes the decision to reward managers and to delegate their powers for the future periods. Performance measurement has especially criterial and incentive function. 


\section{Content and Structural Differences in Financial and Management Accounting}

As already mentioned, the primary cause of different content and structural concepts of financial and management accounting are different requirements of internal and external users of accounting information. Financial accounting system provides information support primarily for external users, who are business owners, investors, employees, business partners, stock exchanges and other interested parties, while the management accounting system provides information support for internal purposes and management control. This information constitutes the basis for decision-making tasks of the managers.

The fact that each of these two systems reflects the needs of different group of users of accounting information results in their dual conception. This comes through especially by:

- different recognition of assets and liabilities;

- different recognition of costs and revenues;

- different measurement (valuation) principles;

- different structure and detail of information displayed.

All these symptoms are very closely related and intertwined with each other, thus they cannot be seen as mutually separated consequences.

In management accounting assets - especially intangible assets - and liabilities can be perceived and recognized differently than in financial accounting. The economic nature of transactions is much more substantial for solving managerial decision problems than their legal form that plays an important role in the financial accounting system.

These differences reset in different definition and recognition of costs and revenues in both accounting systems. It may lead to the different levels of profit / loss for the period measured, which means the differing level of financial performance achieved. Revenues and especially costs are in management accounting differently defined in terms of value expression and measurement, as well as the structure and frequency and moment of their detection and evaluation.

Within the management accounting system a much wider range of measurement is applied. A number of pricing models based on the 
expected future development are applied, while financial accounting is linked to demands for reliability and verifiability.

As a demonstration of the above, we can use a closer look at the income statement, which measures the level of financial performance achieved when combined with the balance sheet. Various demands of users of accounting information lead to the differences between revenues, costs and profit in both accounting systems. It must necessarily be reflected in the structure and content of the income statement. While the financial accounting strives to hide many important details (for example particular factors influencing the gross profit), management accounting, on the contrary, provides very detailed and carefully structured information on these issues. Nowadays, many companies budget and sequentially evaluate this information in five aspects:

- product aspect provides information on how sales from individual products or from groups of products contribute to the performance achieved;

- customer aspect shows how individual customers or customer groups influence the gross profit;

- territorial aspect shows how the profit is influenced by the sales in different territories, where the firm sells its output;

- distribution aspect provides information on how the profit is influenced by the sales via different distribution channels, which the company uses to meet its customers;

- responsibility aspect shows how the individual sellers contribute to the overall profit.

\section{Diminishing of Differences between Financial and Management Accounting System}

Financial accounting in its traditional form is mainly focused on the past, while management accounting provides data for comparison the actual state with the intended one and especially for assessing the alternatives of future development. On the other hand, it should be noted that the financial accounting has experienced continuous development and recent trends aim to capturing the transactions in the context of future benefits.

Development of International Accounting Standards / International Financial Reporting Standards (IAS / IFRS) and especially U.S. Generally 
Accepted Accounting Principles (US GAAP) is under way in accordance with future orientation tendency. It is not legitimate to assume that the systems of financial and management accounting lead to mutual fusion, but it can be argued that the development of IAS / IFRS and US GAAP weakens the causes of a dual concept in a range of areas. What is more, it encourages mutual convergence of both accounting systems (i.e. financial and management accounting).

This tendency can be documented for example by an increasing effort to separate the transactions related to ordinary activities (operating activity) from peripheral or incidental transactions (non-operating activity) (see FASB, 2010).

Another example is the possibility to present the income statement in accordance with US GAAP only with classification of expenses by function (see FASB, 2010). This kind of classification provides better ${ }^{8}$ information on company's performance. Managerial income statement should always be classified primarily by function of expenses, which provides much better information support for management control. The information about nature of expenses is rather complementary and serves as a basis for ensuring proportions, stability and balance between the need for resources and external business environment which is able to provide them (see Král et al., 2010, p. 70).

Another example is the requirement of IAS / IFRS and US GAAP for displaying of lease transactions, which is based on reporting, measuring and depreciating of long-term leased fixed assets by the lessee.

Information needs of managers, however, will always be specific and will stem from very different motives than from the effort to distinguish the information required from the data from financial accounting system. "As traditional view on the management accounting aims, content and structure comes from contrast to financial accounting, recent stage is more characteristic by values whose effort is to overcome its narrowly disciplinary orientation and to find interface to principle question how to incorporate management accounting information into performance management systems by the most effective way (see Král, 2007).

8 Better quality of information on the performance results from the need to recover the factors that influence gross profit. 


\section{Developmental Tendencies of Performance Measurement and Management Accounting}

In previous chapters the trends which result in financial and management accounting convergence were highlighted. This trend reflects both the information structure (an example is increasing effort to separate even in financial accounting impacts related to the major activity from other effects, which are incidental or peripheral nature) as well as its content (an example might be an effort to focus on future impacts in financial accounting, which is reflected in the increasing effort to evaluate a range of asset items in Fair Value). This chapter focuses on the deepening differences between the financial and management accounting. Despite the aforementioned mutual convergence of financial and management accounting, management accounting remains a tool for solving very different problems and, consequently, develops differently than financial accounting in many ways. Many of these "non-converging tendencies" are proved very strongly in the matter of providing information for performance measurement.

Requirements on management (and therefore necessarily also the measurement) of financial performance as a major factor in future growth potential of the business have evolved over time. The evolution, of course, must be reflected by appropriate development of management accounting, as the central instrument of management control. This development causes deepening and strengthening of the dual conception of financial and management accounting.

A number of developmental tendencies pervaded the text in previous chapters of the paper. At this point I consider it appropriate to summarize and organize these tendencies into a list. However, it does not pretend to be a complete listing, but rather strives to highlight the most important trends in measuring the financial performance and in the development of management accounting, which is an important tool for this measurement.

\section{Developmental Trends of Financial Performance Measurement}

The performance of the company has been increasingly perceived as a potential for future success and growth, rather than as a simple glance in the past. The main task of measuring performance is to help to find answers to questions how our present and future decisions and actions 
contribute to the future benefit (see Wagner, 2005, p. 47). Business performance has been thus increasingly seen as a strategic parameter. In the long term, dynamics and success of business development and thus its performance depends mainly on the quality of its strategic management. Strong focus on the future requires the valuation of assets and liabilities, and consequently costs and revenues, based on expected future benefits or sacrifices (estimated present value of future benefits and sacrifices, estimates of market prices, etc.). Management accounting has adapted quite successfully for these requirements, while financial accounting in this regard remains - and must remain - more prudent and consequently more conservative. Valuation tied to future expectations is characterized by very high level of subjectivity, which is unacceptable in financial accounting, where is much more room for risk of abuse of information asymmetry between users and producers of reports informing about the performance.

An important amount of economic resources is spent during the innovation part of product lifecycle. The benefit of these resources, however, is approved by the revenue recognition much later than the expense had incurred. The matching of realized revenues and incurred costs should be based on the length of product lifecycle, rather than on traditional fixed (usually shorter) period. (For more details see Král et al., 2010.) Then it brings much higher information potential. This aspect primarily refers to the creation and use of intangible assets which are cornerstones of competitiveness of the companies today. These assets therefore belong among the most important items of assets (of balance sheet). Time period in which the company achieves benefits from the intangible assets is usually delayed in comparison with the period in which the economic resources were sacrificed and activities that have established the potential to generate future benefits were undertaken. At the moment of sacrificing these economic resources (which means creating of intangible assets) only estimating of future benefits is possible. In this regard financial accounting suffers for its prudence again.

Just described time mismatch between the sacrifice of economic resources and getting the benefit from them is caused by increasing tendency to overcome the discontinuity of performance measurement. This limitation stems, inter alia, from performance measurement based on a fixed time period, for which the desired parameters are planned and budgeted. However, the final comparison may be made only when the evaluated process itself and all its direct consequences had been 
completed. Such aggregated information on the achieved performance can satisfy external users, whose mission is not to actively influence the business. However, such information is insufficient for company's management needs. Managers need to know not only information about the performance as whole, but especially detailed information about the factors that led to its achievement. Such information is, of course, obviously useful for external users too. Knowledge of the causes of performance achieved is an important aspect in further decision-making, because it allows making much better forecasts of future development. Managers of a company are responsible for its management, so they need information on performance as soon as possible. So that it is possible to influence and control the development of performance. It is too late to obtain such information when all processes have already taken place. In terms of time, therefore, demands for information of different groups of users are fundamentally different.

Another trend identified by Wagner (2005) and Král (2007), means the perception of performance as an internal source of the ability to achieve success in the external (market) environment. The objectives of the company and the chosen ways to achieve them, are usually formulated by managers of the company, however, the final performance recognized is always up to the external environment. This trend leads to the perception of business performance as the ability to satisfy the demands of all stakeholders and not only of the owners' ones. This idea is based on stakeholders theory and comes true in practice for example by application of analytical performance measures (an example was mentioned above - it is Balanced Scorecard). In this regard, customer worth of paying special attention, because his or her decision to buy or not to buy the product of the company determines a competitive position of the company and the level of financial performance achieved.

\section{Developmental Tendencies of Management Accounting in Relation to Financial Performance Measurement}

Changes in business environment are accompanied by development in the understanding, perceiving and measuring of performance. These changes must be, of course, reflected in the management accounting to be able to respond in a flexible way.

Many current trends stem from the effort to highlight the strategic perspective and its information support. In this context, however, the 
performance should be seen in broader concept than just as financial performance. In this chapter we will focus on developmental trends that are directly connected to shift in perception of the financial component of performance. These may include in particular (see Král, 2007):

- management accounting as a financial (value) information system;

- financial and non-financial management integrity;

- change in time parameters of accounting information for operational and tactical management;

- multidimensionality of management and its information support.

\section{Management accounting as a financial (value) information system}

Management accounting is still linked to traditional concept of accounting information, however, especially the pressure on the timeliness, richness and originality of the information for future decisionmaking makes it necessary to abandon the strict application of all elements of the accounting methodology. The information is often transformed beyond the double-entry accounting principles (such as product costing).

This trend is also documented by the above mentioned effort of management accounting to react to current issues of performance measurement. The effort results in increasing the scope of management accounting. Management accounting is defined rather by its user orientation (i.e. focus on the needs and demands of managers) than by the type of information (which would meet the characteristics of genuine accounting information) (Wagner, 2005).

\section{Financial and non-financial management integrity}

There has been an increasingly strong pressure on linkage financial information with the natural (material) aspect of the business process. Complex performance measurement systems such as Balanced Scorecard, which links financial performance measures with a number of nonfinancial (natural) criteria, can be a suitable example.

The integrity also presents itself by tight linking of value quantities with natural aspect of the business process. It is necessary to see the specific operation or activity behind each piece of value information as 
well as the specific purpose of the expenditure of reasonable amount of economic resources.

\section{Change in time parameters of accounting information}

This change relates primarily to information for operational and tactical control. Pressure on the speedy presentation of accounting information is evident. Management accounting is abandoning the principles of reliability and relevance, because they necessarily imply a rigidity and delay of information. Management accounting focuses on providing a variety of reports reflecting the managerial needs with minimal time delay.

Due to the risks arising from information asymmetry the information with a high level of reliability has of course exceptional value in financial accounting. It is usually associated with reduction in timeliness of such information, however, it is an acceptable sacrifice for information credibility gained. It is not necessary to assume such strong conflict between interests of users and producers of management accounting information. It is therefore not necessary to separate the information that meets defined and harmonized requirements for the reliability from other information. It is possible to use not quite reliable and objective but timely information without a greater risk.

\section{Multidimensionality of management and its information support}

Manager, who manages business in today's complex and aggressive business environment, requires good information on the development of relevant variables in many aspects (points of view) simultaneously. These days it is standard practice to monitor information in the management line (aspect) of products, activities, sub-processes, processes, responsibility centres, customers, sales territories, distribution channels and possibly other useful aspects.

In my opinion, the financial accounting does not utilise the potential for assessment of financial performance, because it does not use the number of above mentioned aspects, in which information could be monitored. Financial accounting shows the reality only in a single aspect. While trying to find one - the most correct - point of view seems to be quite naive and by far not the best, financial accounting still sticks to this effort quite stubbornly. Evidence is the approach of IASB, which is 
reflected by the conceptual framework of IAS / IFRS. It says that the financial statements which meet the needs of investors also meet the most of needs of other users (see IASB, 2009).

Each group of users has its own information needs. If it is possible to strive for fulfillment of needs of all the groups, it is a shame to settle for a compromise approach described above. Demands of all stakeholders can never be fully satisfied in this case.

The generally accepted definitions of accounting features include the view of accounting as the purpose-oriented model of a company. Groups of many interested people, who strive for different goals, imply a lot of purposes, for which the accounting could and should serve. Monitoring and reporting of information in several aspects (dimensions) together (which is much easier these days thanks to the level of information technology development ${ }^{9}$ would greatly increase the explanatory power of financial statements.

This approach obviously implies the need to differentiate between user groups. While using the internal information system of a company workers on different positions have different access rights to data store, it is also possible to differentiate between external users. For example, an investor who holds $40 \%$ of shares or bank that contributes significantly to the capital of the company will gain more detailed information in different structure than for example ordinary employees or even competitors.

\section{The role of management accounting in performance assessment}

Performance management can be considered as a primary goal of managers. Managing business performance means influencing the development of the company that was entrusted to manager's care in order to optimally fulfill the objectives which the company has been

9 Let us mention the possibility of storing data in one central data store, in which each piece of information has a number of different attributes that reflect different views of different user groups. Differentiated demands for performance information are then only a matter of filtering data in the required structure and in the required database dimension due to database technologies and tools. 
founded for. Such a responsible task can be performed only with a sufficiently wide range of adequate source information.

Thoughts about the role of management accounting in financial performance measurement, of course, cannot depend on whether management accounting itself (respectively its tools) can measure business performance, but rather on its integration with other systems and on its role in these relationships.

Performance management should necessarily integrate all the functions of a high-quality management control system, which means organizational function, planning function, controlling function, motivation function and last but not least, the information function, which penetrates all the above mentioned. Management accounting can be considered as an information tool of performance management system, so it can be characterized as an information-oriented performance management subsystem.

Now it is necessary to revert to question what is actually the scope and extent of management accounting. Former in the text the integration of information from financial and management accounting as well as from other professional disciplines (marketing, management, logistics or others) including information from the external environment of the company was commented. This complex integration of information leads to the fact that management accounting goes beyond its traditional scope (which means orientation exclusively to accounting and/or financial information).

This complex and modern perception of management accounting means linkage with other fields related to the comprehensive management of the company. It can ensure the performance measurement methods in a wider meaning by comprehensive information support.

In the traditional approach to performance (for example in accordance with CIMA's definition, as defined above in the text) only financial (value) measures are included in scope of management accounting, while the measures of performance are often based as well on natural criteria. That is why the management accounting as an information support for the performance management system plays only a partial role. 
The fact that the role of management accounting in performance management system is only partial, however, does not imply that management accounting, which has traditionally focused rather on operational and tactical level of management control, is not an appropriate management tool. The possibility of effective strategic performance management must necessarily be supported by effective operational and tactical procedures. In this regard, the role of management accounting is important. It is necessary to become aware of its proper linking to strategic objectives.

Fig. 2: Hierarchy of Management Control

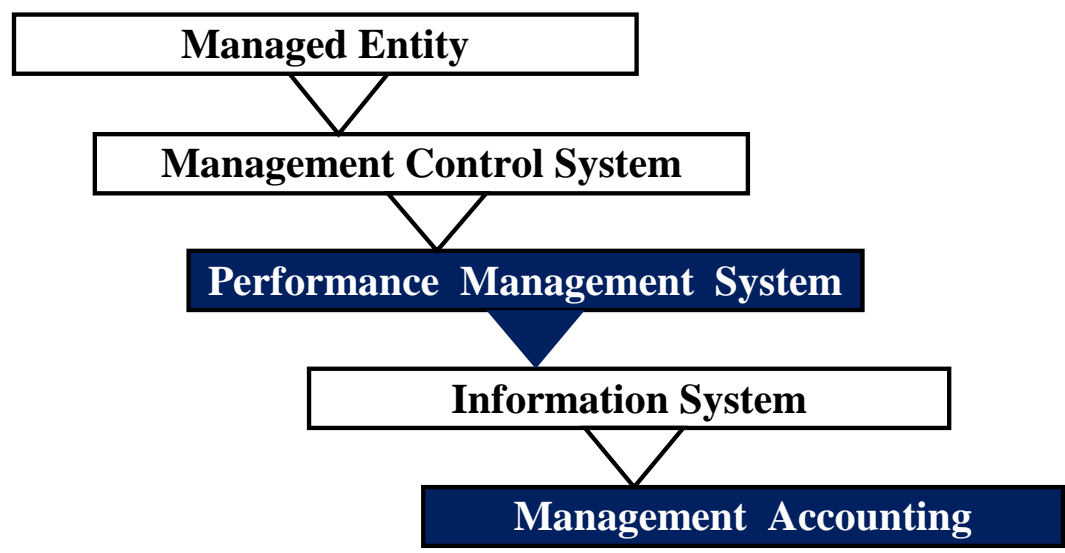

Source: Author's own elaboration

The mutual hierarchy makes clear that both management accounting and performance management system are influenced primarily by demands for efficient management control. However, this relationship should be also seen in reverse order. A prerequisite of effective management control is that both the performance management system, as well as management accounting system operate in conformity with each other and provide high-quality information to enable appropriate assessment of reality. That is the irreplaceable function of both these systems.

\section{Conclusion}

Turbulent and aggressive competitive environment of today's world increasingly forces organizations to understand business performance rather as a future potential ability to succeed in the marketplace than as 
plain view on the present or the past. One of major components of this broadly understood business performance is financial performance. In today's business environment an increasing emphasis is therefore placed on finding high-quality information about financial performance. A highquality information system becomes a necessity. Accounting subsystem includes financial information, which creates conditions for effective management of financial performance. Such information helps all interested parties to understand the direction and causes of company's development.

While managing performance the managers strive to influence the economic subjects' development by a rational way - so that they would be able to fulfill the aims they have been founded for. Financial performance, which is based on traditional financial indicators, is a hierarchically subordinated item of complex evaluation of business performance. It is just one - albeit important - part of the performance.

Performance measurement is significantly affected by user dimension. From the perspective of business management performance is a very broad-perceived characteristic, which reflects whether the company meets its objectives or not. From the perspective of external users performance is narrowed to assessing the financial performance and is limited by the accounting regulations.

Many financial variables are differently defined in terms of value expression and measurement, as well as the structure and frequency and moment of their recognition and evaluation in management accounting.

However, the natural emergence of two separate accounting systems may not (and even should not) necessarily imply two different approaches to the conception of performance measurement. The different needs of different users require a different structure and sometimes even different content of output information or statements about the performance achieved, but they not require different conception of performance itself.

The duality of financial and management accounting has been weakened by developments in two of the world's most notable financial systems IAS / IFRS and US GAAP. It is possible to observe the tendency to capture the transactions in the context of future benefits. Examples of these trends can be strict separation of transactions connected with major 
(operating) activities, classification of expenses by their function (at least under US GAAP), reporting leasing transactions and others.

On the other hand, the demands for performance measurement as well as for management accounting as a tool to meet these demands, has been developing very dynamically. It results in strengthening of manifestations of duality and the widening of differences between the systems of financial and management accounting. Management accounting remains a tool for solving very different problems and, consequently, develops differently than financial accounting in many ways.

The performance of the company has been increasingly perceived as a potential for future success and growth, rather than as a simple glance in the past. Business performance has been thus increasingly seen as a strategic parameter. Increasing tendency to overcome the discontinuity of performance measurement has been taking place. This effort stems from performance measurement based on a fixed time period, for which the desired parameters are planned and budgeted. However, the final comparison may be made only when the evaluated process itself and all its direct consequences had been completed. Performance has been increasingly perceived as an internal source of the ability to achieve success in the external (market) environment. The objectives of the company and the chosen ways to achieve them, are usually formulated by managers of the company, however, the final performance recognized is always up to the external environment. Management accounting has adapted quite successfully for these requirements, while financial accounting in this regard remains - and must remain - more prudent and consequently more conservative.

These changes must be, of course, reflected in the management accounting which is an important tool for measuring and managing performance to be able to respond in a flexible way. Developmental trends that are directly connected to shift in perception of the financial component of performance may include:

- management accounting as a financial (value) information system;

- financial and non-financial management integrity;

- change in time parameters of accounting information for operational and tactical management;

- multidimensionality of management and its information support. 
Managerial perceived comprehensive performance management system requires besides financial criteria also a number of natural criteria. Performance management system goes far beyond the management accounting itself. Management accounting can be considered as an information tool of performance management system, so it can be characterized as an information-oriented performance management subsystem. The role of management accounting in performance management system is only partial, but still crucial.

Despite the dynamic development of financial accounting, thanks to which external users have better information on the development of performance, there are many important aspects that are still denied to external users. They receive information broken down according to whether the transaction relates to the core business or not. However, despite increasing emphasis on the assessment of future benefits (fair value valuation) all the information is bounded by demands for prudence and reliability, which can significantly weaken their explanatory power. Reports compiled in several dimensions together would allow satisfying the demands for reliability and prudence of information displayed as well as enabling reporting of information which could support decisions on future matters, although burdened with a much greater degree of subjectivity.

\section{References}

[1] CIMA (1982): Management Accounting - Official Terminology. London, Chartered Institute of Management Accountants, 1982.

[2] Fibírová, J. - Šoljaková, L. - Wagner, J. (2005): Nákladové účetnictví. Manažerské účetnictví I. (In English: Cost Accounting. Management Accounting I.) Prague, Oeconomica, 2005.

[3] FASB (2010): Statements of Financial Accounting Concepts; Statements of Financial Accounting Standards. [On-line], Norwalk, Financial Accounting Standards Board, 2010, [cit. $8^{\text {th }}$ November, 2011], 〈www.fasb.org/st>.

[4] Halír, Z. (2010): The Role of Accounting Information in Financial Performance Measurements from External User's Viewpoint. European Financial and Accounting Journal, 2010, Vol. 5, No. 2, pp. 25-52. 
Halîr, Z.: Accounting System and Financial Performance Measurements.

[5] IASB (2009): International Financial Reporting Standards 2007. London, International Accounting Standards Board, 2009.

[6] Král, B. (2007): Řízení výkonnosti a manažerské účetnictví. (In English: Performance Management and Managerial Accounting.) In Král, B. et al. (ed.): Koncepce a praxe řízení výkonnosti. (In English: Theory and Practice of Performance Management.) Praha, Oeconomica, 2007, pp. 83-101.

[7] Král, B. et al. (2010): Manažerské účetnictví. (In English: Management Accounting). Praha, Management Press, 2010.

[8] Wagner, J. (2005): Potenciál účetních informací pro měrení finanční výkonnosti. (In English: Potential of Accounting Information for Performance Measurement.) Praha, University of Economics in Prague, 2005, Doctoral Thesis.

[9] Wagner, J. (2009): Měrení výkonnosti. (In English: Performance Measurement.) Praha, Grada, 2009. 


\title{
Accounting System and Financial Performance Measurements
}

\author{
Zbyněk HALÍR̆
}

\begin{abstract}
The paper concerns measuring and reporting of financial performance of an enterprise. Currently increasing emphasis is placed on performance measurement and management. Within performance measurement and management in general the role of financial performance is becoming increasingly important. The paper is concerned with measuring and reporting of financial performance of an enterprise primarily from manager's point of view. In its first part it deals primarily with the connection between the performance of an enterprise in general and financial performance. In subsequent part it is about the relation of performance management and management accounting. The next part of the paper is devoted to the dual concept of financial and management accounting and to causes and consequences of the duality. Then it summarizes the most important developmental tendencies of financial performance measurement and management accounting.
\end{abstract}

Key words: Performance Measurement; Financial Performance; Management Accounting; Dual Concept.

JEL classification: M41. 